\title{
MISJE I REKOLEKCJE REDEMPTORYSTÓW W LATACH 1939-1945
}

Zgromadzenie Najświętszego Odkupiciela w Polsce w czasie II Wojny światowej złożyło dużą ofiarę krwi i cierpienia slużąc Bogu i Ojczyźnie. Nie ustawało jednak w swojej pracy rekolekcyjno-misyjnej mimo wiclorakich utrudnień ze strony władz okupacyjnych.

W historiografii polskiej istnieje już opracowanie O. Mariana Brudzisza poświęcone wojennym dziejom Zgromadzenia ${ }^{1}$. Zagadnienie dzialalności rekolekcyjno-misyjnej zostało tam jedynie zasygnalizowane. W artykule niniejszym starano się nieco bardziej przybliżyć tego rodzaju prace apostolskie.

W 1939 r. polska prowincja redemptorystów posiadala klasztory w Krakowie, Mościskach, Warszawie, Wilnie, Zamościu, Lubaszowej, Łomnicy Zdroju oraz Toruniu i Lwowic. Te dwa ostatnie zostaly zlikwidowane przez władze okupacyjne we wrześniu 1939 r. na ich miejsce w 1942 r. otwarto hospicjum w Kielcach-Karczówce i Lublinie ${ }^{2}$. Ponadto przez cały okres okupacji istniały: juwenat, nowicjat, seminarium (tzw. studentat) i drugi nowicjat - jako szkola bezpośredniego przygotowania do pracy misyjnej ${ }^{3}$. W dniu wybuchu drugiej wojny światowej placówki te liczyly 78 kapłanów (7 na misji argentyńskiej) i 35 braci. W następstwie wojny i okupacji 6 ojców wyemigrowało, 2 zginęło w Zamościu 8 VII 1940 r., 4 zostalo wywiezionych do obozów koncentracyj-

1 M. Brudzisz, Redemptoryści. W: Życie religijne w Polsce pod okupacja hitlerowskn 1939-1945. Pod red. ks. Z. Zielińskiego. Warszawa 1982, s. 709-721.

2 Archivum Prowincji Warszawskiej Redemptorystów w Tuchowie, dawniej w Warszawie (APR), Littere Annales de rebus gestis Prozincine Polonine Congregationis SS. Redemptoris 1939-1945. (LAP). T. 5, s. 1-23, 120-144.

3 M. Brudzisz, Losy seminarium duchoinnego Ojców Redemptorystóiw w latach 1939-1945. W: Kościót Katolicki un zieminch polskich to czasie drugiej wojmy świntowej. Materialy i studia. Pod red. ks. F. Stopniaka. T. 7, z. 3. Warszawa 1978 , s. 36-46. 
nych, 15 rozstrzelanych 6 VIII 1944 r. w Warszawie (razem z 9 braćmi i 6 klerykami), 5 zmarło śmiercia naturalną, 2 opuściło zgromadzenie. Jednocześnie w latach 1939-1945, wyświęcono w Tuchowie 22 nowych kaplanów4.

Działalność misyjno-rekolekcyjna utrudniały: bieda, brak odzieży i obuwia, epidemie, niesprzyjajace warunki atmosferyczne (Zawoja, Wroderyż). Żywe były wplywy komunizmu wśród pewnych grup społecznych i antyklerykalizm, a także bandytyzm (Młodzawy, Michalów); następnie przepisy i zarządzenia wydane przez okupanta, a więc godzina policyjna (Kraków-Podgórze), na wsi obowiązek różnych prac przymusowych na rzecz Niemców (Zawoja); animozje między ludnością polską a przybyłymi kolonistami niemieckimi (Rzędzianowice, Gąspów) i antagonizmy narodowe (Wilno). Kilkakrotnie $w$ czasie misji nastapily lapanki i aresztowania (Kurzelów, Stopnica, Podbieziu - Litwa) oraz przemarsze wojsk, które paraliżowały bądź nawet przerywały prace (Szczucin, Olesno, Wilczyska, Gołków, Łuszonice, Męcina, Sralowa $)^{5}$.

Wśród wielu czynników negatywnych będacych przeszkodą $w$ pracach apostolskich znajdowały się i takie, które dotyczyły samych misjonarzy. Mianowicie niezbędne były przepustki na podróż koleja, bardzo trudne do uzyskania. Niektórzy ojcowie, gdy przepustki nie otrzymali, wybierali się do parafii pieszo, inni rezygnowali i prace odwolywali. Wyjątek stanowil o. J. Sochacki, który w sytuacjach beznadziejnych potrafil zawsze załatwić przepustki w odpowiednim urzędzie. Poza tym samo podróżowanie było trudem pełnym obaw przed rewizjami i aresztowaniem ${ }^{6}$.

Misje i rekolekcje redemptorystów, to nadzwyczajna forma duszpasterstwa, bazująca na pracy parafialnej. Tego typu działalność wymagala odpowiedniego przygotowania i spokoju. W interesujacym nas okresie (1939-1945) brakowało elementarnych warunków do przeprowadzania prac apostolskich. Ze wszystkich stron każdy czuł się zagrożony, gdyż wydano wyrok śmierci na caly naród polski oraz na wszystko, co stanowilo o jego bycie ${ }^{7}$. Pomimo terroru, braku swobód i ograniczeń w zakresie życia religijnego, redemptoryści decydowali się na kontynuowanie swego tradycyjnego apostolatu. Aby spelnić to zadanie $w$ warunkach okupacji, potrzeba było dużo odwagi ze strony duszpasterzy i misjonarzy. Jak wskazuja źródła, tacy kapłani się znaleźli i tylko dzięki tej grupie odważnych zapaleńców nie zaprzestano prowadzenia misji, renowacji i rekolckeji, mimo chwilowej przerwy na przclomic 1939

+ APR, LAP t. 5, s. 1-21.

5 Archiwum Klasztoru Redemptorystów w Krakowie (AKRK), Kronika dornu krikowskiego, t. 3, s. 967-1176.

6 O. W. Szoldrski, Redemptoryści to Polsce, s. 162-167, mps. Relacja o. J. Dochniaka z 22 IV 1982.

7 J. Kloczkowski, L. Mullerowa, J. Skarbek, Zarys Kościoła w Polsce. Kraków 1986, s. 340-356. 
i 1940 r. ${ }^{8}$. Redemptorystów często zapraszali kaplani zaprzyjaźnieni, korzystający od lat z poslugi zgromadzenia (Biegonice, Łomnica, Mogilno, Narama, Ociesęki, Piotrkowice Jędrzejowskie, Siemiechów, Zawoja) ${ }^{9}$, jak również tacy, którzy pragnęli udzielić redemptorystom pomocy materialnej - głównie żywnościowej - w ich ciężkim położeniu. „Wobec niektórych bliskich Tuchowowi parafii mieliśmy dlug wdzięczności, bo ludzie od ust sobie odejmowali, by nas wesprzeć swoimi datkami. Do tych księży jechało się z wdzięczności, by pomóc w spowiedzi, wygłosić parę kazań w ramach "quasi" rekolekcji i - najczéściej - by otrzymać nowe datki"10. Nierzadko jednak prace organizowali kapłani mający placówkę daleko od głównych traktów komunikacyjnych, w glębi lasów, gdzie często władzę sprawowały oddzialy partyzanckie (Cisów, Rogów) ${ }^{11}$. Redemptoryści również, jak stwierdza jeden z ojców, "wkręcali się, gdzie się dało". Za mistrza w tym dziele moźna uznać o. Tadeusza Grodniewskiego, który często wyjeżdżal "w górki”, do znajomych księży ${ }^{12}$. Ale największy przyrost prac misyjno-rekolekcyjnych nastapil w 1943 r., albowiem wówczas - m.in. w archidiecezji warszawskiej, diecezji sandomierskiej, tarnowskiej, kieleckiej - biskupi nakazali przeprowadzić rekolekcje parafialne ${ }^{13}$. Najaktywniejszy w dziele okazał się ordynariusz kielecki, bp Czesław Kaczmarek, który zarządził w każdej parafii misje lub rekolekcje ${ }^{14}$.

$\mathrm{Na}$ terenach wschodnich II Rzeczypospolitej również organizowano prace apostolskie, ale w ograniczonym zakresie $\mathrm{i}$ to dopiero pod okupacją niemiecką. Działalność taką inspirowała polska hierarchia kościelna na czele z abpem Romualdem Jałbrzykowskim, który organizowal i wysyłal grupy kapłanów na tereny pozbawione księży w okolice Mińska, Mohylewa, Witebska, Połocka, Smoleńska. Grupy te chrystianizowały tereny, które od I wojny światowej należały do Rosji Radzieckiej. W jednej z takich grup działal - w Prozorkach, Konstantynowie, Eyntupach, Postawach i okolicach - o. Jan Dochniak od sierpnia 1941 do maja 1942 r. Przeprowadził tam 13 prac apostolskich ${ }^{15}$.

W okresie okupacji redemptoryści nie mogli całkowicie poświęcić się dziełu misyjnemu. Na przeszkodzie stały wszystkie czynniki nierozerwalnie związane z wojną. Dlatego w latach 1940 -1942 misje prowadzono sporadycznie. Klasztor

8 APR, A. Grabe, Pamiętniki, t. 2, s. 78; Relacja o. K. Franczyka z 30 IX 1982; Relacja o. K. Lendziona z 1 V 1982.

9 AKRK, Kronika, t. 3, s. 966-967, Relacja o. E. Kowalkowskiego z 6 VI 1984.

10 Relacja o. F. Kowalczyka z 30 IV 1984; Relacja o. K. Franczyka z 30 IX 1983.

11 Relacja Ks. J. Pluty z 19 XI 1983.

12 Relacja Ks. R. Feliksa z 10 VII 1983; o. J. Kroka z 20 IV 1982.

13 Ks. A. Zapart, Diecezja snndonierska. W: Życie religijne..., dz. cyt., s. 246 . Ks. B. Kumor, Diece-ja tanousskn, tamże, s. 263. o. W. Szoldrski, dz. cyt., t. 2, s. 114. Relacja o. K. Holdy z 25 IV 1984.

14 Ks. M. Paulewicz, Diecezjn kieleckn,. W: Życie religijne..., dz. cyt., s. 243; Ks. S. Wilk, Salezjanie, tamże, s. 734.

15 AKRK, Kronika domu wileńskiego, t. 1, s. 266-270. Relacja o. J. Dochniaka z 22 IV 1982. 
krakowski przeprowadzil wówczas 6 prac. On też jako pierwszy wznowil misje, - praca $w$ Piotrkowicach Jędrzejowskich (25 II - 3 III 1940 r.). Dopicro jednak w latach 1943-1944 następuje wzrost ich liczby. W 1944 r. placówka krakowska przeprowadziła 18 prac misyjnych i 1 renowacje. Klasztor ten w czasie okupacji działal najbardziej aktywnie podejmując się realizacji 31 misji i 5 renowacji misyjnych ${ }^{16}$. Drugie miejsce zajmuje hospicjum $w$ Kielcach-Karczówce z 9 misjami i 1 renowacja, następnie Tuchów: 4 misje i 4 renowacje, Łomnica Zdrój: 1 misja i 1 renowacja, Wilno 1 renowacja ${ }^{1 \%}$. Łącznie w latach 1939-1945 redemptoryści przeprowadzili 45 prac misyjnych i 12 renowacji $w$ nastepujących diecezjach: kieleckiej (35 misji, 4 renowacje), krakowskiej ( 6 misji, 3 renowacjc), tarnowskiej ( 3 misje, 2 renowacje), przemyskiej (1 misja, 2 renowacje), wileńskiej ( 1 renowacja). Warto $w$ tym miejscu wspomnieć również o misji obejmujacej cale Kielce (23 III - 4 IV 1944 r.). Zorganizowal ją bp Czesław Kaczmarek $i$ aktywnie wspomagal modlitwa, słuchaniem spowiedzi i ciaglym zachęcaniem wiernych, aby zechcieli z niej skorzystać. Na życzenie biskupa w czasie misji szczególnie zwracano uwage na: moralność $w$ rodzinach - szerzej w naukach dla rodziców, obowiązek uczestniczenia w Mszy świętej, konieczność spowiedzi ${ }^{1 \delta}$. We wszystkich pozostałych misjach i renowacjach stosowano przedwojenne schematy i metody w stopniu, na jaki pozwalały warunki wojenne i okupacyjne. Najpelniej ilustruje to misja w Lubaszowej (11-20 IX 1942 r.), w czasie której misjonarze zachowali tradycyjną strukturę i glosili kazania o: Zbawieniu Duszy, Różańcu, Spowiedzi, Śmierci, Piekle, Sądzie Bożym, Milości Bliźniego. Święceniu Niedzieli i Świąt, Szóstym I Siódmym Przykazanı. Cala misja miała jeden podstawowy cel - doprowadzić człowieka do nawrócenia i do spowiedzi odprawianej przed misjonarzami, jeżeli istniala taka możliwość. Misja kończyła się Komunią Generalna wszystkich stanó ${ }^{19}$.

Obok misji i renowacji glówną formą oddzialywania apostolskiego redemptorystów byly rekolekcje parafialne, które $\mathrm{z}$ racji działań wojennych zostały zawieszone do $1940 \mathrm{r}$. Wznowiono je w lutym owego roku. Przeprowadzono ich jednak niewiele. Przelomorry był rok 1943, z powodu zmiany kursu władz niemieckich wobec Kościoła. Wówczas wzrasta nagle ilość przeprowadzonych rekolekcji parafialnych. Świadczy o tym dobitnie - między innymi następujace zestawienie: podczas gdy klasztor tuchowski w latach 1940-1942 przeprowadzil 12 rekolckeji, to $w$ przelomowym 1943 r. az 73 . Podobriy proces wzrostu wystapił $w$ innych klasztorach, chociaż ich aktywność była zróżnicowana i przedstawiała się następujaco: Tuchów (130), Kraków (109),

16 APR, LAP, s. 25-28; AKRK Księgn prac apostolskich klasztoru krakouskiego wo latach 1939-1945, S. $158-320$.

17 APR, LAP, s. 22-145.

Is AKRK, Kronikn, t. 3, s. 1165; 1179-1182.

19 APR, o. J. Bitko, Wsponmienia, z. 3, s. 422-426. 
Warszawa (52), Mościska (26), Kielce-Karczówka (24), Wilno (24), Lublin (11), Zamość (8), tomnica-Zdrój (7). Wynikiem tego dynamizmu apostolskiego było przeprowadzenie podczas okupacji przez redemptorystów przynajmniej 430 serii rekolekcji parafialnych $w 9$ diecezjach. Najwiecej tych prac stwierdzono w diecezji tarnowskiej (175), kieleckiej (80), warszawskiej (62), krakowskiej (34) oraz diecezji lubelskiej (19), wileńskiej (12), przemyskiej (14), lwowskiej (10), sandomierskiej (8), częstochowskiej (6) ${ }^{20}$. Rekolekcje byly przeznaczone dla calej parafii lub dla jednego stanu. Zazwyczaj trwaly od trzech do ośmiu dni i ich program byl zależny od lokalnych uwarunkowań społecznych i religijnych. W czasie nauk rekolekcyjnych poruszano podstawowe prawdy wiary, zagadnienie Opatrzności Bożej, prawdy wieczne, problem cierpienia i panującego $w$ świecie zła oraz bolączki parafian np: pijaństwo, donosicielstwo. Gloszono przynajmniej jedną naukę o spowiedzi. W kilkunastu parafiach księża pragnęli formalnej misji, ale ze względu na warunki wojenne nie można bylo jej przeprowadzić. Odprawiano więc sześciodniowe rekolekcje "per modum missionis" z naukami stanowymi i spowiedzią generalna ${ }^{21}$. Warto także odnotować 244 serii rekolekcji zamkniętych dla następujących grup rekolektantów: siostry zakonne (117 serii) zakonnicy (39), świeccy (39), księża (37), alumni seminariów duchownych (12) Najwięcej tych prac przeprowadzil dom warszawski $(91)^{22}$.

W rekolekcjach brało udział wielu ludzi bezpośrednio zaangażowanych w ruchu oporu przeciw okupantom. O. Stanisław Solarz w swoich wspomnieniach $\mathrm{z}$ tego okresu, tak opisal swoje zetknięcie się $\mathrm{z}$ partyzantami w parafii Wierna w czasie rekolekcji: - „zupelnie brakowało młodzieży na naukach rekolekcyjnych. Ale gdy zbliżala się pora nauki stanowej dla młodzieży męskiej, łańcuch ludzi z lasu napelnil kościól. Do spowiedzi wszyscy przyszli. Po Mszy dziękowali za naukę $w$ naszym duchu. Podniesiony na duchu wróciłem do twierdzy hitlerowskiej - Krakowa, gdzie wszystko bylo "nur für Deutsche"23.

Ojcowie, którzy zetknęli się z czlonkami ruchu oporu twierdzili, że dla tych ludzi problemem życiowym bylo tylko zagadnienie, czy uwięzionemu człowiekowi będącemu u kresu wytrzymałości, z obawy, aby drugich nie zdradzić, wolno zażyć truciznę..? I co zrobić, gdy organizacja wyda wyrok śmierci i poleci go wykonać na nieznanych im ludziach?24. O. Jan Dochniak wspomina, że rekolekcje w Służanach (50 km od Wilna), 19-21 Il 1944, "przeszły w podnioslym nastroju. W kościele święcono sztandary, spotkalem się $z$ dowódca brygady partyzanckiej «Lopuszką". Gdy

\footnotetext{
20 APR, LAP, s. 22-144.

21 AKRK, Kronika, t. 3, s. 1194; 1136-1141.

22 APR, LAP, s. 22-144.

23 APR, o. S. Solarz, Pamiętniki, s. 55-61.

24 Relacja o. K. Franczyka z 30 IX 1982.
} 
spowiadałem $w$ kościele, widziałem, jak błyskaly w slońcu helmy polskich żolnierzy" 25 .

Cała działalność misyjno-rekolekcyjną $w$ różnym stopniu i wymiarze prowadziło 68 redemptorystów. Najaktywniejsi z nich należeli do klasztoru krakowskiego. Byli to: o. Tadeusz Grodniewski - który przeprowadzil 31 misji, 5 renowacji i 79 rekolekcji parafialnych oraz wyglosil kilkadziesiąt kazań okolicznościowych i konferencji dla sióstr, o. Józef Sochacki z 36 pracami misyjno-rekolekcyjnymi, o. Franciszek Marcinek, o. Marian Pirożyński - każdy z 23 pracami misyjno-rekolekcyjnymi. Ze wspólnoty tuchowskiej następujący ojcowie najczęściej prowadzili prace apostolskie: o. Kazimierz Holda, 91 serii rekolekcji różnego typu i 1 misję, o. Jan Bilko 51 różnych prac, o. Stanisław Wójcik, który przeprowadzil 41 serii rekolekcji i 1 misję, a także o. Dominik Stawarz z 23 rekolekcjami i 1 misja i o. Józef Puchalik z 24 rekolekcjami. W Kielcach najaktywniejszy byl o. Karol Szrant z 36 pracami, w Wilnie 0 . Jan Dochniak z 17 pracami, w Łomnicy - o. Stanisław Zdunek 16 prac. O. Konstanty Franczyk, dzialający w latach 1939-1945 na trzech placówkach: w Warszawie, Krakowie, Kielcach, wygłosil 26 serii misyjno-rekolekcyjnych ${ }^{26}$.

Podsumowując należy stwierdzić, że redemptoryści jako jedni z nielicznych podjęli się prowadzenia misji $\mathrm{i}$ rekolekcji oraz szeregu innych akcji pastoralnych. Cały ten apostolat podtrzymywał ludzi na duchu, dawal nadzieje i rozbudzal wiare w lepsze jutro, wzmacniał patriotyzm i poczucie tożsamości narodowej; uczulał na potrzeby bliźnich oraz przywracał ludziom godność wtedy, gdy ja straszliwie deptano.

25 Relacja o. J. Dochniaka z 22 IV 1982.

26 AKRK, Księgn prac apostolskich klasztoru krakowskiego w latach 1939-1945, s. 158-320. 